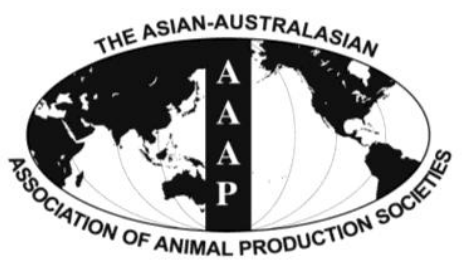

Asian-Aust. J. Anim. Sci.

Vol. 25, No. 3 : 375 - 381

March 2012

www.ajas.info

http://dx.doi.org/10.5713/ajas.2011.11323

\title{
Predicting the Digestible Energy of Rapeseed Meal from Its Chemical Composition in Growing-finishing Pigs
}

\author{
T. Zhang, L. Liu and X. S. Piao* \\ State Key Laboratory of Animal Nutrition, China Agricultural University, \\ No. 2. Yuanmingyuan West Road, Beijing 100193, China
}

\begin{abstract}
Two experiments were conducted to establish a digestible energy (DE) content prediction model of rapeseed meal for growing-finishing pig based on rapeseed meal's chemical composition. In experiment 1, observed linear relationships between the determined DE content of 22 rapeseed meal calibration samples and proximate nutrients, gross energy (GE) and neutral detergent fiber (NDF) were used to develop the DE prediction model. In experiment 2, 4 samples of rapeseed meal selected at random from the primary rapeseed growing regions of China were used for testing the accuracy of DE prediction models. The results indicated that the DE was negatively correlated with NDF $(r=-0.86)$ and acid detergent fiber (ADF) $(r=-0.73)$ contents, and moderately correlated with gross energy $(\mathrm{GE} ; \mathrm{r}=0.56)$ content in rapeseed meal calibration samples. In contrast, no significant correlations were found for crude protein, ether extract, crude fiber and ash contents. According to the regression analysis, NDF or both NDF and GE were found to be useful for the DE prediction models. Two prediction models: $\mathrm{DE}=16.775-0.147 \times \mathrm{NDF}\left(\mathrm{R}^{2}=0.73\right)$ and $\mathrm{DE}=11.848-0.131 \times \mathrm{NDF}+0.231 \times \mathrm{GE}\left(\mathrm{R}^{2}=\right.$ 0.76) were obtained. The maximum absolute difference between the in vivo DE determinations and the predicted DE values was 0.62 $\mathrm{MJ} / \mathrm{kg}$ and the relative difference was $5.21 \%$. Therefore, it was concluded that, for growing-finishing pigs, these two prediction models could be used to predict the DE content of rapeseed meal with acceptable accuracy. (Key Words : Pig, Rapeseed Meal, Digestible Energy)
\end{abstract}

\section{INTRODUCTION}

Rapeseed meal (RSM) is the second most widely traded protein ingredient after soybean meal representing a $12.40 \%$ of the world protein meal production, reaching 207 million metric tons in 2004 and 2005 (Ash and Dohlman, 2006). Rapeseed meal is readily available and could present an alternative and economical source of dietary protein for feed. After oil extraction, rapeseed meal has a high content of crude protein (35-40\%, Näsi and Siljander-Rasi, 1991; $30-40 \%$, Roth-Maier et al., 2004) and a higher neutral detergent fiber (NDF) content than soybean meal because hulls are not eliminated and represent about $30 \%$ of the meal; this causes a lower digestible energy content than that of soybean meal (2.6 vs. 3.4 Mcal/kg; Bell, 1993).

There is very little data on the digestible energy (DE) or metabolizable energy (ME) value of RSM, but RSM is widely used in pig diets. Therefore, it is important to estimate precisely the energy value of RSM, both for least

\footnotetext{
* Corresponding Author : Xiangshu Piao. Tel : +86-10-6273-3588, Fax : +86-10-6273-3688, E-mail : piaoxsh@mafic.ac.cn Submitted Sept. 9, 2011; Accepted Oct. 27, 2011; Revised Nov. 1, 2011
}

cost formulation purposes and for adapting the feed supply to the energy requirements of animals. In vivo digestibility studies with pigs to estimate the nutritive values of feed ingredients are a time-, cost-, and labor-intensive process; hence, the prediction of DE content from chemical composition, which can be determined rapidly in vitro, can be a useful tool for addressing DE variation and for accurate diet formation. Several factors can affect the accuracy of DE prediction models, which subsequently influence their successful use. One such factor is the sample size for regression analysis; another is the representative value of samples for the feedstuff as a whole (Zhao et al., 2008). Prediction models from smaller sample sizes may have greater $\mathrm{R}^{2}$ and less residual standard deviation (RSD), but may not be as accurate as other models developed with a greater number of samples. On the other hand, the range of DE and chemical composition contents of samples obviously affect the accuracy of the prediction model. For example, low variation in DE and chemical composition contents of samples might provide an incorrect prediction model (Carré, 1990). Therefore, this study utilized 22 calibration samples comprising rapeseed meals from different regions or different production styles, containing a 
Table 1. Growth location and chemical composition of RSM (DM basis \%, MJ/kg), experiment 1

\begin{tabular}{llcrrrrrrrr}
\hline Item $^{1}$ & Growth location & CP & CF & EE & Ash & NDF & ADF & GE & Ca & P \\
\hline RSM-HUB & Hubei & 43.05 & 13.70 & 0.64 & 10.99 & 45.48 & 27.78 & 19.19 & 0.91 & 0.98 \\
RSM-NM & Neimenggu & 42.28 & 13.91 & 2.35 & 7.84 & 37.80 & 26.42 & 20.02 & 0.76 & 0.95 \\
RSM-HUN & Hunan & 41.36 & 14.88 & 1.18 & 8.73 & 48.64 & 23.68 & 19.59 & 0.83 & 0.81 \\
RSM-GZ & Guizhou & 38.04 & 13.95 & 0.43 & 12.92 & 50.05 & 32.20 & 15.70 & 0.71 & 0.66 \\
RSM-WP & Hubei & 40.87 & 19.06 & 3.34 & 8.73 & 45.57 & 26.88 & 20.46 & 0.79 & 0.84 \\
RSM-WPN & Hubei & 59.02 & 14.63 & 0.76 & 10.28 & 49.90 & 15.44 & 20.91 & 0.93 & 0.36 \\
RSM-WP1 & Hubei & 35.96 & 17.79 & 2.32 & 5.89 & 63.30 & 44.05 & 21.08 & 1.14 & 0.39 \\
\hline
\end{tabular}

${ }^{1}$ Mean of three determinations per sample. $\mathrm{CF}=$ Crude fiber; ADF = Acid detergent fiber; NDF = Neutral detergent fiber; GE $=$ Gross energy; EE = Ether extract.

large range of different chemical compositions, to establish DE or ME prediction models for growing-finishing pigs.

\section{MATERIALS AND METHODS}

Swine DE and ME assay all procedures were approved by the Institutional Animal Care and Use Committee at China Agricultural University, Beijing.

\section{Difference method}

The difference method is recommended when high levels of raw materials cannot be used because of toxicity or lack of palatability (Knabe et al., 1989). Due to its high level of fiber (Bell, 1993; Mińkowski, 2002) and its negative effect on feed intake, RSM is not recommended as the sole protein source in pigs when used to estimate its DE and ME. For this reason, the difference method was used. Preliminary observations were conducted on 10 pigs $(35 \pm 1.1 \mathrm{~kg}$ of BW) fed graded quantities $(10 \%, 15 \%, 20 \%$ and $25 \%$ ) of RSM indicated that the inclusion level of RSM at $15 \%$ would maintain normal feed intake. In the experiment 1 and 2, the control diet was a corn-soybean meal diet and the experiment diets replaced $15 \%$ of the corn-soybean meal with RSM.

\section{Diets}

The objective of experiment 1 was to determine the relationship between DE (or ME) and the chemical composition of 22 RSM samples to develop a prediction model for DE or ME that could be utilized for the formulation of diets for growing-finishing pigs. Seven samples of prepress-solvent extracted RSM from 4 main rape production areas in China were collected from July to September 2010 (Table 1). The rapeseed meal of RSM-WP, RSM-WP1 and the protein-rich rapeseed meal production of RSM-WPN were produced by the Hubei Weipu Biological Technology Company. The 22 rapeseed meal calibration samples (Table 2) were made by combining different percentages of rapeseed meal to provide a wide range of proximate nutrient compositions and a big sample size. The composition and nutrient content of the diets used in experiments 1 and 2 is presented in Table 3. In experiment 2, four prepress-solvent extracted RSM from different regions of China were used to test accuracy of the prediction models obtained in experiment 1 (Table 4).

\section{Animals and experimental design}

Experiments 1 and 2 were done simultaneously. Thirty Duroc $\times($ Landrace $\times$ Large White) castrated male pigs weighing $30.5 \pm 2.1 \mathrm{~kg}$ were used in five incomplete Latin squares $(6 \times 6)$. Each diet was measured with 6 pigs. The control diet was fed to two pigs in each experiment period, meaning the control diet was measured with 12 pigs. The pigs were placed individually in metabolism cages provided

Table 2. The composition of calibration RSM, experiment 1

\begin{tabular}{|c|c|c|c|c|c|c|c|}
\hline \multirow{2}{*}{$\begin{array}{l}\text { Calibration } \\
\text { RSM } \\
\text { sample }\end{array}$} & \multicolumn{7}{|c|}{ RSM sample ingredients (\%) } \\
\hline & HUB & $\mathrm{NM}$ & HUN & GZ & WP1 & WP & WPN \\
\hline 1 & - & - & - & - & 7 & 91 & 2 \\
\hline 2 & - & - & - & - & 14 & 82 & 4 \\
\hline 3 & - & - & - & - & 23 & 70 & 7 \\
\hline 4 & - & - & - & - & 31 & 60 & 9 \\
\hline 5 & - & - & - & - & 39 & 49 & 12 \\
\hline 6 & - & - & - & - & 47 & 39 & 14 \\
\hline 7 & - & - & - & - & 20 & 80 & - \\
\hline 8 & - & - & - & - & 27 & 59 & 14 \\
\hline 9 & - & - & - & - & 31 & 48 & 21 \\
\hline 10 & - & - & - & - & 35 & 36 & 29 \\
\hline 11 & - & - & - & - & 39 & 25 & 36 \\
\hline 12 & - & - & - & - & 72 & 28 & - \\
\hline 13 & - & - & - & - & 52 & 48 & - \\
\hline 14 & 40 & - & - & - & - & 60 & \\
\hline 15 & - & - & - & - & - & 100 & - \\
\hline 16 & - & - & 35 & - & - & 65 & - \\
\hline 17 & - & - & 74 & - & - & 26 & - \\
\hline 18 & - & - & - & 28 & - & 72 & - \\
\hline 19 & - & - & - & 37 & - & 63 & - \\
\hline 20 & - & - & - & 47 & - & 53 & - \\
\hline 21 & - & - & - & 66 & - & 34 & - \\
\hline 22 & - & - & - & 85 & - & 15 & - \\
\hline
\end{tabular}


Table 3. Ingredient composition (\%, as-fed basis) of control and experimental diets

\begin{tabular}{|c|c|c|c|}
\hline \multirow{2}{*}{$\begin{array}{l}\text { Ingredient } \\
\text { Corn }\end{array}$} & \multirow{2}{*}{$\begin{array}{c}\text { Control diet } \\
(\mathrm{n}=2)\end{array}$} & \multicolumn{2}{|c|}{$\begin{array}{c}\text { Experimental diets } \\
\text { (experiment } 1: \mathrm{n}=22 ; \text { experiment } 2: \mathrm{n}=4 \text { ) }\end{array}$} \\
\hline & & \multicolumn{2}{|c|}{65.705} \\
\hline Soybean meal & 18.6 & \multicolumn{2}{|c|}{15.81} \\
\hline Rapeseed meal & 0 & \multicolumn{2}{|c|}{14.4} \\
\hline L-lysine & 0.1 & \multicolumn{2}{|c|}{0.085} \\
\hline Dicalcium phosphate & 0.9 & \multicolumn{2}{|c|}{0.9} \\
\hline Calcium carbonate & 0.9 & \multicolumn{2}{|c|}{0.9} \\
\hline Carrier-medical stone & 0.9 & \multicolumn{2}{|c|}{0.9} \\
\hline Salt & 0.3 & \multicolumn{2}{|c|}{0.3} \\
\hline Minerals and vitamins premix ${ }^{1}$ & 1 & \multicolumn{2}{|c|}{1} \\
\hline Total & 100 & \multicolumn{2}{|c|}{100} \\
\hline Analyzed nutrient content & & Mean & Range \\
\hline $\mathrm{DM}$ & 87.71 & 88.21 & 87.78 to 89.31 \\
\hline $\mathrm{CP}$ & 16.43 & 18.82 & 17.38 to 19.76 \\
\hline $\mathrm{CF}$ & 2.73 & 4.75 & 3.44 to 5.61 \\
\hline $\mathrm{EE}$ & 1.66 & 1.58 & 1.50 to 1.67 \\
\hline Ash & 5.29 & 6.34 & 5.93 to 7.29 \\
\hline $\mathrm{NDF}$ & 13.31 & 17.34 & 13.13 to 19.68 \\
\hline $\mathrm{ADF}$ & 5.29 & 8.95 & 7.37 to 9.73 \\
\hline
\end{tabular}

${ }^{1}$ Supplied per kilogram of diet: vitamin A (retinyl acetate), 4,500 IU; vitamin $\mathrm{D}_{3}, 1,400 \mathrm{IU}$; vitamin $\mathrm{E}$ (DL- $\alpha$-tocopheryl acetate), $13.5 \mathrm{IU}$; vitamin $\mathrm{K}_{3}, 2.7$ $\mathrm{mg}$; thiamin, $0.9 \mathrm{mg}$; riboflavin, $2.7 \mathrm{mg}$; pyridoxine, $1.4 \mathrm{mg}$; vitamin $\mathrm{B}_{12}$ (cobalamin), $9 \mu \mathrm{g}$; pantothenate, $11 \mathrm{mg}$; folate, $0.60 \mathrm{mg}$; biotin, $0.04 \mathrm{mg}$; choline chloride, $350 \mathrm{mg}$; copper $\left(\mathrm{CuSO}_{4} \cdot 5 \mathrm{H}_{2} \mathrm{O}\right), 18 \mathrm{mg}$; iron $\left(\mathrm{FeSO}_{4} \cdot 7 \mathrm{H}_{2} \mathrm{O}\right), 75 \mathrm{mg}$; zinc $\left(\mathrm{ZnSO}_{4}\right), 70 \mathrm{mg}$; manganese $\left(\mathrm{MnSO}_{4} \cdot \mathrm{H}_{2} \mathrm{O}\right), 20 \mathrm{mg}$; selenium $\left(\mathrm{Na}_{2} \mathrm{SeO}_{3}\right), 0.3 \mathrm{mg}$; iodine (KI), $0.35 \mathrm{mg}$.

with a feeder and a nipple watering device set in a room with controlled temperature $\left(19 \pm 2^{\circ} \mathrm{C}\right)$. Pigs were adapted to the digestibility cage for a period of $10 \mathrm{~d}$ before the collection of feces and urine. The whole experiment would be divided into 6 phases of collection of feces and urine, each phase lasts $10 \mathrm{~d}$. The first $5 \mathrm{~d}$ of each phase were for feed adaptation and the last $5 \mathrm{~d}$ were for separate and total collection of feces and urine. Feed quantity was increased gradually during the experiment period. This feeding level represents about $90 \%$ of the spontaneous feed intake of the cage-housed pigs. All the pigs received their diets twice daily ( 0830 and $1530 \mathrm{~h}$ ) in two equal meals and had free access to water.

For each diet, a sample of feed was collected and measured for its DM content and subsequently used for chemical analyses. Each day, feces and acidified (with $\mathrm{H}_{2} \mathrm{SO}_{4}$ to reach a pH below 2.0) urine were collected. Daily urine and feces collection were cumulated and stored at $-20^{\circ} \mathrm{C}$. Collected feces were then homogenized and subsampled for DM analysis and freeze-dried for further chemical analyses at the end of the collection period.

\section{Chemical analyses}

The AOAC (2000) methods were used for measuring moisture, ash, crude protein $(\mathrm{N} \times 6.25$; Kjeltec, 2100$)$, Weende crude fiber $(\mathrm{CF})$, and crude fat (extracted with petroleum ether; Soxtec Avanti 2050; Foss, Höganäs, Sweden). The ADF and NDF contents of feedstuffs were determined according to the procedure described by Van Soest (1963) and Van Soest et al. (1991). Samples of rapeseed meal, diets, feces and urine were analyzed for gross energy (GE) via adiabatic oxygen bomb calorimeter (Parr Instruments, Moline, IL, UAS).

\section{Calculations and statistical analyses}

Gross energy consumed was calculated by multiplying

Table 4. Growth location and chemical composition of testing RSM (DM basis \%, MJ/kg), experiment 2

\begin{tabular}{llrrrrrrrrrrr}
\hline Item & $\begin{array}{l}\text { Growth } \\
\text { location }\end{array}$ & CP & CF & EE & Ash & NDF & ADF & GE & DE & DE/GE & Ca & P \\
\hline RSM-XJ & Xinjiang & 43.38 & 9.60 & 1.92 & 7.62 & 35.74 & 16.68 & 19.86 & 11.23 & 0.57 & 0.83 & 0.79 \\
RSM-HEN & Henan & 40.19 & 14.28 & 3.54 & 11.86 & 42.30 & 23.09 & 19.39 & 11.19 & 0.58 & 0.78 & 0.97 \\
RSM-FJ & Fujian & 41.49 & 13.23 & 2.06 & 7.18 & 30.82 & 22.31 & 20.00 & 12.26 & 0.61 & 0.70 & 1.03 \\
RSM-SC & Sichuan & 44.75 & 15.52 & 0.65 & 6.10 & 37.29 & 23.81 & 19.87 & 11.91 & 0.60 & 0.25 & 0.96 \\
\hline
\end{tabular}


Table 5. Correlation coefficients between chemical composition and DE (ME) of calibration samples, experiment 1

\begin{tabular}{|c|c|c|c|c|c|c|c|c|c|}
\hline & $\mathrm{CP}$ & $\mathrm{CF}$ & $\mathrm{EE}$ & ASH & NDF & $\mathrm{ADF}$ & GE & $\mathrm{DE}$ & $\mathrm{ME}$ \\
\hline $\mathrm{CP}$ & 1 & & & & & & & & \\
\hline $\mathrm{CF}$ & -0.15 & 1 & & & & & & & \\
\hline $\mathrm{EE}$ & -0.22 & -0.24 & 1 & & & & & & \\
\hline ASH & -0.14 & -0.63 & -0.07 & 1 & & & & & \\
\hline $\mathrm{NDF}$ & -0.37 & 0.30 & 0.06 & 0.04 & 1 & & & & \\
\hline $\mathrm{ADF}$ & -0.33 & 0.14 & -0.03 & 0.15 & 0.63 & 1 & & & \\
\hline GE & 0.21 & 0.21 & -0.02 & -0.49 & -0.48 & -0.56 & 1 & & \\
\hline $\mathrm{DE}$ & 0.39 & -0.38 & -0.02 & 0.03 & -0.86 & -0.73 & 0.56 & 1 & \\
\hline ME & 0.27 & -0.11 & 0.11 & -0.40 & -0.29 & -0.46 & 0.44 & 0.45 & 1 \\
\hline
\end{tabular}

the GE value of the diet fed by feed intake over the $5 \mathrm{~d}$ collection period. Apparent DE values were calculated by subtracting fecal energy from intake energy. Apparent ME values were calculated by subtracting urinary energy from apparent DE.

Data were analyzed by ANOVA using the procedure of SAS. In all analyses, $\mathrm{p}<0.05$ was considered significant. Simple regression analyses were conducted to establish prediction equations.

\section{RESULTS}

The growth location and nutrients of RSM used in experiment 1 and 2 were presented in Table 1 and 4 . Excluding the protein-rich rapeseed meal production of RSM-WPN, the range of RSM crude protein were 35.96 to $44.75 \%$ on a dry matter basis; residual ether extracts $0.43 \%$ to $3.54 \%$; crude fiber 9.6 to $19.06 \%$; ash 5.89 to $12.92 \%$; calcium 0.25 to $1.14 \%$; and phosphorus 0.39 to $1.03 \%$. Crude protein of RSM-WPN was $59.02 \%$ on a dry matter basis; residual ether extracts $0.76 \%$; crude fiber $14.36 \%$.

The correlation coefficients between chemical composition and DE (ME) of calibration samples in experiment 1 were presented in Table 5. The results indicated that the DE was negatively correlated with $\mathrm{NDF}(\mathrm{r}$ $=-0.86)$ and $\operatorname{ADF}(r=-0.73)$ contents and moderately
Table 6. Prediction equations of the DE (MJ/kg of DM) values of rapeseed meal according to neutral detergent fiber (NDF) and gross energy (GE) contents (\%, DM basis), experiment 1

\begin{tabular}{lccc}
\hline Prediction equation & $\mathrm{R}^{2}$ & $\mathrm{RSD}$ & $\mathrm{p}$-value \\
\hline $\mathrm{DE}=16.775-0.147 \times \mathrm{NDF}$ & 0.73 & 0.85 & $<0.01$ \\
$\mathrm{DE}=11.848-0.131 \times \mathrm{NDF}+0.231 \times \mathrm{GE}$ & 0.76 & 0.82 & $<0.01$ \\
\hline
\end{tabular}

correlated with gross energy $(\mathrm{GE} ; \mathrm{r}=0.56)$ content in rapeseed meal calibration samples. In contrast, no significant correlations were found for $\mathrm{CP}$, ether extract, $\mathrm{CF}$, and ash contents. There were no significant correlations between ME and the other chemical compositions. The absolute correlation coefficients between ME and the other chemical compositions were less than 0.5 , so it is not necessary to build a ME prediction model.

Prediction equations to the DE values of RSM according to NDF and GE contents were presented in Table 6. Two prediction models: $\mathrm{DE}=16.775-0.147 \times \mathrm{NDF}\left(\mathrm{R}^{2}=\right.$ $0.73)$ and $\mathrm{DE}=11.848-0.131 \times \mathrm{NDF}+0.231 \times \mathrm{GE}\left(\mathrm{R}^{2}=0.76\right)$ were obtained. To test the suitability of these prediction models to predict the DE content of RSM, the DE and ME content of four samples of RSM were measured by both the in vivo method and prediction models in experiment 2 (Table 7). The maximum absolute difference between the in vivo $\mathrm{DE}$ determinations and the predicted $\mathrm{DE}$ values was

Table 7. Comparison of ME contents in rapeseed meal determined by using the in vivo method and prediction model, experiment 2

\begin{tabular}{|c|c|c|c|c|c|c|c|}
\hline \multirow{2}{*}{ Test RSM } & \multirow{2}{*}{$\begin{array}{l}\text { Observed DE } \\
(\mathrm{MJ} / \mathrm{kg})\end{array}$} & \multicolumn{3}{|c|}{$\begin{array}{c}\text { Equation 1: } \\
\mathrm{DE}=16.775-0.147 \times \mathrm{NDF}\end{array}$} & \multicolumn{3}{|c|}{$\begin{array}{c}\text { Equation } 2: \\
\mathrm{DE}=11.848-0.131 \times \mathrm{NDF}+0.231 \times \mathrm{GE}\end{array}$} \\
\hline & & $\begin{array}{l}\text { Predicted DE } \\
(\mathrm{MJ} / \mathrm{kg})\end{array}$ & $\begin{array}{l}\text { Difference } \\
(\mathrm{MJ} / \mathrm{kg})\end{array}$ & $\begin{array}{c}\text { Difference } \\
(\%)\end{array}$ & $\begin{array}{l}\text { Predicted DE } \\
(\mathrm{MJ} / \mathrm{kg})\end{array}$ & $\begin{array}{c}\text { Difference } \\
(\mathrm{MJ} / \mathrm{kg})\end{array}$ & $\begin{array}{c}\text { Difference } \\
(\%)\end{array}$ \\
\hline RSM-XJ & 11.23 & 11.52 & 0.29 & 2.59 & 11.75 & 0.52 & 4.63 \\
\hline RSM-HEN & 11.19 & 10.56 & -0.63 & -5.63 & 10.79 & -0.4 & -3.58 \\
\hline RSM-FJ & 12.26 & 12.25 & -0.01 & -0.09 & 12.43 & 0.17 & 1.39 \\
\hline RSM-SC & 11.91 & 11.29 & -0.62 & -5.21 & 11.55 & -0.36 & -3.03 \\
\hline Mean & 11.65 & 11.41 & & & 11.63 & & \\
\hline SD & 0.53 & 0.70 & & & 0.67 & & \\
\hline p-value & & & 0.3677 & & & 0.9419 & \\
\hline
\end{tabular}


$0.62 \mathrm{MJ} / \mathrm{kg}$ and the relative different was $5.21 \%$.

\section{DISCUSSION}

The increased cost of the inclusion of SBM as a protein supply for pig diets has promoted interest into alternative sources of protein. One such substitute source is RSM. The presence of anti-nutritional factors such as glucosinolates, tannins, sinapine and erucic acid are found to affect the nutritional value of RSM as a protein source for pigs (Mawson et al., 1993). The potential of RSM as a pig feed component is also limited by its high crude fiber content, almost double that of SBM (124 vs. $60 \mathrm{~g} / \mathrm{kg}$; Sauvant et al., 2004) and this in turn reduces the energy value and nutrient digestibility of the diet (Fenwick, 1982). Yong-Gang Liu (1994) reported that results were obtained from more than 200 RSM samples from various oil mills in China. For screw-pressed cake and prepress-solvent extracted meal, respectively, crude protein averaged 389 and $432 \mathrm{~g} / \mathrm{kg}$ on a dry matter basis; residual lipids 106 and $19 \mathrm{~g} / \mathrm{kg}$; crude fiber 132 and $138 \mathrm{~g} / \mathrm{kg}$; ash 87 and $99 \mathrm{~g} / \mathrm{kg}$; calcium 8 and 9 $\mathrm{g} / \mathrm{kg}$; phosphorus 11 and $12 \mathrm{~g} / \mathrm{kg}$. In the current study, excluding the protein-rich rapeseed meal production of RSM-WPN, the range of RSM crude protein were 38.04 to $44.75 \%$ on a dry matter basis; and crude fiber 9.6 to $19.06 \%$. The crude protein content of RSM-WPN was $59.02 \%$, and crude fiber $14.63 \%$. The large range of chemical compositions of RSM used in the current study was benefit to the accuracy of the prediction model.

Noblet and Perez (1993) proposed prediction equations for the digestibility of nutrients and energy values of pig mixed diets from chemical analysis. The results showed that the DE was negatively correlated with NDF $(r=-0.80)$, $\mathrm{ADF}(\mathrm{r}=-0.72)$ and $\mathrm{CF}(\mathrm{r}=-0.71)$ contents. In the current study, the DE was negatively correlated with NDF ( $\mathrm{r}=$ -0.86) and $\mathrm{ADF}(\mathrm{r}=-0.73)$ similarly, while barely correlated with CF $(r=-0.38)$. According to the high correlation between $\mathrm{DE}$ and fiber content, the single predictor was always the fiber estimate. Among the different fiber estimates, the predictions with the lowest RSD were obtained with NDF alone as CF or ADF alone were inferior predictors. A few studies comparing different fiber criteria (King and Taverner, 1975; Morgan et al., 1987; Noblet et al., 1989) also concluded that NDF was a more accurate predictor than ADF or CF.

The DE of Canola RSM (B. campestris) was found to be $14.15 \mathrm{MJ} / \mathrm{kg}$ dry matter and energy digestibility was $71 \%$ (Bell et al., 1981). Bourdon and Aumaitre (1990) reported that the DE of high-glucosinolate RSM was $13.42 \mathrm{MJ} / \mathrm{kg}$ and energy digestibility was $68.5 \%$ based on dry matter. In our experiment 1 , the average DE content of 22 RSM calibrations was $10.17 \mathrm{MJ} / \mathrm{kg}$ and the energy digestibility was $56 \%$ (data not shown). In our experiment 2 , the average
DE content of 4 testing RSM was $11.65 \mathrm{MJ} / \mathrm{kg}$ and the energy digestibility was $59 \%$.

The DE content is relative with the chemical content, physical property, rapeseed cultivar and quality, etc. The high fiber content in RSM originates mainly from a high hull content of about 25 to $30 \%$. Rapeseed hulls contain about $60 \%$ NDF, of which lignin constitutes almost $50 \%$ (Grala et al., 1998). Mitaru et al. (1984) reported that the fiber of rapeseed hulls decreases ileal digestibilities of all nutrients in pigs. Studies carried out by De Lange et al. (1990) and Grala et al. (1998), demonstrated that rapeseed fiber (NDF) considerably affects ileal losses of dietary and endogenous nitrogen in pigs.

The nutritional value of rapeseed meal may vary among samples in China. Seneviratne et al. (2010) showed that extraction of oil from rapeseed meal in solvent-extraction plants was more efficient than in expeller pressing plants, resulting in a lower DE and ME content in solvent-extracted rapeseed meal. The process used for oil extraction could affect the nutrition value of RSM by leaving different amounts of oil or by decreasing the fiber content through dehulling (Bourdon et al., 1982). In the current study, to exclude the effects of different production procedures, we chose ten rapeseed meals taken from solvent-extraction production. Bayley et al. (1969) demonstrated the DE content of B. campestris RSM was $11.58 \mathrm{MJ} / \mathrm{kg}$ when tested as $40 \%$ of a corn-soybean diet fed to 45 to $90 \mathrm{~kg}$ gilts. When pelleted and reground, the DE value increased to $12.68 \mathrm{MJ} / \mathrm{kg}$.

Bell (1975) found low DE of $1,750 \mathrm{kcal} / \mathrm{kg}(7.32$ $\mathrm{MJ} / \mathrm{kg})$ for Bronowski RSM and 2,520 kal $/ \mathrm{kg}(10.54$ $\mathrm{MJ} / \mathrm{kg}$ ) for a commercial sample of B. campestris RSM. It is reported that the Bronowski cultivar was not adapted to the region where the test sample was grown and consequently, the seed harvested was immature and of poor quality. The DE values shown do not reflect the possibly higher value of B. campestris RSM $(3,210 \mathrm{kcal} / \mathrm{kg}, \mathrm{DM})$ compared with B. napus RSM (3,370 kcal/kg, DM) (Bush et al., 1978; Sharma et al., 1980).

In the current study, the maximum absolute difference between the in vivo DE determinations and the predicted DE values was $0.62 \mathrm{MJ} / \mathrm{kg}$ and the relative different was $5.21 \%$. In the 10th revised edition of Nutrition Requirements of Swine (Subcommittee on Swine Nutrition Committee on Animal Nutrition. 1998), the Canola RSM (DM, 90\%) has $21.2 \% \mathrm{NDF}$ and $2,885 \mathrm{kcal} / \mathrm{kg}$ DE content; on a DM basis, the DE value is $3,205 \mathrm{kcal} / \mathrm{kg}(13.46 \mathrm{MJ} / \mathrm{kg})$. Using the prediction model, $\mathrm{DE}=16.775-0.147 \times \mathrm{NDF}$, we calculate the $\mathrm{DE}$ value as $13.66 \mathrm{MJ} / \mathrm{kg}$. The absolute difference between the DE value of Nutrition Requirements of Swine and the predicted DE values was $0.20 \mathrm{MJ} / \mathrm{kg}$, and the relative difference was $1.49 \%$. Therefore, the two prediction models in this article can be used to predict the 
DE content of RSM for growing-finishing pigs with acceptable accuracy.

Some specific equations for prediction of DE value of raw materials such as cereals (Wiseman and Cole, 1980), wheat by-products (Batterham et al., 1980a), sunflower meal (Perez et al., 1986), and cassava meal (INRA, 1984), etc. were reported. The comparison of different prediction equations is difficult because they do not propose the same predictors; they were not established from comparable sets of diets, and the digestibility measurements were obtained under different physiological conditions (body weight of the pigs, feeding level, etc.) (Noblet and Perez, 1993). It would be logical to favor the equations with the lowest residual standard deviation, practically applicable (low interlaboratory standard deviation and cost of analysis), and established with a large number of chemically variable diets, each diet being analyzed by different laboratories (Noblet and Henry, 1993).

The reasons for these differences between measured energy values and those estimated from equations are unclear. However, it is relatively well established that the digestive utilization of diets is increased when body weight of animals increased and (or) feeding level is markedly reduced (Cunningham et al., 1962; Everts et al., 1986). In addition, the results (Noblet and Shi, 1993) indicated significant interactions existed between chemical characteristics of the diet (or dietary energy density) and body weight, physiological stage, or feeding level: the effect of these factors on DE values was negligible for highly digestible diets and was most important for lowenergy diets. The RSM contained high CF content, so the effect of these factors on DE value can not be ignored. Furthermore, the dietary fiber indicators (e.g., NDF, ADF) are not easy to measure or values obtained in different labs may be rather different. The equations proposed from our experiments should then be used with caution. Additional measurements are required to confirm our findings and increase the number of samples per category.

\section{ACKNOWLEDGEMENTS}

The work was supported by the China Postdoctoral Science Foundation funded project (20110490481), Chinese Universities Scientific Fund (2011BH004), the National Nature Science Foundation of China (31072040) and State Key Laboratory of Animal Nutrition of China (2004DA125184-0810).

\section{REFERENCES}

AOAC. 2002. Official methods of analysis, 17th ed. Association of Official Analytical Chemists, Arlington, VA.

Ash, M. and E. Dohlman. 2006. Oil crops situation and outlook yearbook. Electronic outlook report from the economic research service. United States Department of Agriculture.

Batterham, E. S., C. E. Lewis, R. F. Lowe and C. J. McMillan. 1980. Digestible energy content of cereals and wheat byproducts for growing pigs. Anim. Prod. 31:259-271.

Bayley, H. S., C. Y. Cho and J. D. Summers. 1969. Growth and digestibility studies to evaluate rapeseed meal as a protein supplement for swine. Can. J. Anim. Sci. 49:367.

Bell, J. M. and F. X. Aherne. 1981. Canola meal for pigs. In: Canola meal for Livestock and Poultry (Ed. D. R. Clandinin), Pub 59. Canola Council of Canada, Winnipeg, Manitoba.

Bell, J. M. 1975. Utilization of protein supplements in animal feeds. In: Oilseed and Pulse Crops in Western Canada: A symposium. Western Co-operative Fertillizers Ltd., Calgary, Alberta: 633-656.

Bell, J. M. 1993. Factors affecting the nutritional value of canola meal: a review. Can. J. Anim. Sci. 73:679-697.

Bourdon, D. and A. Aumaitre. 1990. Low-glucosinolate rapeseeds and rapeseed meals: effect of technological treatments on chemical composition, digestible energy content and feeding value for growing pigs. Anim. Feed Sci. Technol. 30:175-191.

Bourdon, D., P. Quere and J. J. Baudet. 1982. Valeur énergétique et azotée, chez le porc, d'un tourteau de colza francais à faible teneur en glucosinolates et dépelliculé. J. Rech. Porc. Fr., 14:297-306.

Bush, R. S., J. W. G. Nicholson, T. M. Maclntyre and R. E. McQueen. 1978. A Comparison of Candle and Tower rapeseed meals in lamb, sheep and beef retions. Can. J. Anim. Sci. 58:369

Carré, B. 1990. Predicting the dietary energy value of poultry feeds. Pages 283-300 in Feedstuff Evaluation (Ed. J. Wiseman, and D. J. A. Cole). Butterworths, London, UK.

Cunningham, H. M., D. W. Friend and J. W. G. Nicholson. 1962. The effect of age, body weight, feed intake and adaptability of pigs on the digestibility and nutritive value of cellulose. Can. J. Anim. Sci. 42:167.

De Lange, C. F. M., W. B. Souffrant and W. C. Sauer. 1990. Real ileal protein and amino acid digestibilities in feedstuffs for growing pigs as determined with the $15 \mathrm{~N}$-isotope dilution technique. J. Anim. Sci. 68:409-418.

Everts, H., B. Smits and A. W. Jongbloed. 1986. Effect of crude fibre, feeding level and body weight on apparent digestibility of compound feeds by swine. Netherlands Journal of Agricultural Science 34:501.

Zhao, F., H. F. Zhang, S. S. Hou and Z. Y. Zhang. 2008. Predicting metabolizable energy of normal corn from its chemical composition in adult Pekin ducks. Poult. Sci. 87:1603-1608.

Fenwick, G. R. 1982. The assessment of a new protein source rapeseed. Proc. Nutr. Soc. 14:277-288.

Grala, W., M. W. Verstegen, A. J. Jansman, J. Huisman and P. van Leeusen. 1998. Ileal apparent protein and amino acid digestibilities and endogenous nitrogen losses in pigs fed soybean and rapeseed products. J. Anim. Sci. 76:557-568.

INRA, 1984. L'alimentation des Monogastriques (porc, lapin, volailles). INRA, Paris, 282.

King, R. H. and M. R. Taverner. 1975. Prediction of the digestible energy in pig diets from analyses of fibre contents. Anim. Prod. 21:275-284.

Knabe, D. A., D. C. LaRue, E. J. Gregg, G. M. Martinez and T. D. Tanksley. 1989. Apparent digestibility of nitrogen and amino 
acids in protein feedstuffs by growing pigs. J. Anim. Sci. 67: 441-458.

Liu, Yong-Gang, Mei-Qin Zhou and Man-Li Liu. 1994. A survey of nutrients and toxic factors in commercial rapeseed meal in China and evaluation of detoxification by water extraction. Anim. Feed Sci. Technol. 45:257-270.

Mawson, R., R. K. Heaney, Z. Zdunczyk and H. Kozlowska. 1993. Rapeseed meal-glucosinolates and their antinutritional effects. Part 3. Animal growth and performance. Nahrung/Food. 38: 167-177.

Mińkowski, K. 2002. Influence of dehulling of rape seed on chemical composition of meal. Anim. Feed Sci. Technol. 96: 237-244.

Mitaru, B. N., R. Blair, R. D. Reichert and W. E. Roe. 1984. Dark and yellow rapeseed hulls, soybean hulls and a purified purified fiber source: Their effects effects on dry matter, energy and amino acid digestibilities in cannulated pigs. J. Anim. Sci. 59:1510-1518.

Morgan, C. A., C. T. Whittemore, P. Phillips and P. Crools. 1987. The prediction of the energy value of compounded pig foods from chemical analysis. Anim. Feed Sci. Technol. 17:81-107.

Näsi, M. and H. Siljander-Rasi. 1991. Effects of thermal processing on digestibility and protein utilization of rapeseed meal of medium and low glucosinolate type in diets for growing pigs. J. Agric. Sci. Finl. 63:475-482.

Noblet, J. and J. M. Perez. 1993. Prediction of digestibility of nutrients and energy values of pig diets from chemical analysis. J. Anim. Sci. 71:3389-3398.

Noblet, J. and Y. Henry. 1993. Energy evaluation systems for pig diets: a review. Livest. Prod. Sci. 36:121-141.

Noblet, J. and X. S. Shi. 1993. Comparative digestibility of energy and nutrients in growing pigs fed ad libitum and adult sows fed at maintenance. Livest. Prod. Sci. 34:137.

Noblet, J., H. Fortune, S. Dubois and Y. Henry. 1989. Nouve Ues bases d'estimation des teneurs en énergie digestible, métabolisable et nette des aliments pour le porc. Inra, Paris, 106.
Perez, J. M., D. Bourdon, J. J. Baudet and J. Evrard. 1986. Prédiction de la valeur énergétique des tourteaux de tournesol à partir de leurs teneurs en constituants pariétaux. Journ. Rech. Porcine Fr. 18:35-42.

Roth-Maier, D. A., B. M. BöÖhmer and F. X. Roth. 2004. Effect of feed canola meal and sweet lupin (L. luteus, L. angustifolus) in animo acid balanced diets on growth performance and carcass characteristics of growing-finishing pigs. Anim. Res. $53: 21-34$

Sauvant, D., J. M. Perez and G. Tran. 2004. Tables of composition and nutritional value of feed materials: pigs, poultry, cattle, sheep, goats, rabbits, horses, fish. Wageningen Academic Publishers, Wageningen, Netherlands and INRA editions, Versailles, France.

Seneviratne, R. W., M. G. Young, E. Beltranena, L. A. Goonewardene, R. W. Newkirk and R. T. Zijlstra. 2010. The nutritional value of expeller-pressed canola meal for growerfinisher pigs. J. Anim. Sci. 88:2073-2083.

Sharma, H. R., J. R. Ingalla and T. J. Devlin. 1980. Apparent digestibility of tower and candle repeseed meals by Holstein bull calves. Can. J. Anim. Sci. 60:915.

Subcommittee on Swine Nutrition Committee on Animal Nutrition. 1998. Nutrition Requirements of Swine. 10th revised edition. National Academy Press, Washington, DC, USA.

Van Soest, P. J. 1963. Use of detergents in the analysis of fibrous feeds. II. A rapid method for the determination of fiber and lignin. J. Am. Off. Anal. Chem. 46:829-835.

Van Soest, P. J., J. B. Robertson and B. A. Lewis. 1991. Methods for dietary fiber, neutral detergent fiber, and nonstarch polysaccharides in relation to animal nutrition. J. Dairy Sci. 74:3583-3597.

Wiseman, J. and D. J. A. Cole. 1980. Energy evaluation of cereals for pig diets. In: Recent Advances in Animal Nutrition (Ed. W. Haresign). Butterworths, London, pp. 51-67. 